Canadian University Music Review

Canadian University Music Review

Revue de musique des universités canadiennes

\title{
The Organized Muse? Organization Theory and "Mediated" Music
}

\section{James Deaville}

Volume 18, numéro 1, 1997

Crossing Borders: Interdisciplinary Studies by Canadian Scholars Franchir les frontières : études interdisciplinaires de chercheurs canadiens

URI : https://id.erudit.org/iderudit/1014819ar

DOI : https://doi.org/10.7202/1014819ar

Aller au sommaire du numéro

\section{Éditeur(s)}

Canadian University Music Society / Société de musique des universités canadiennes

\section{ISSN}

0710-0353 (imprimé)

2291-2436 (numérique)

Découvrir la revue

\section{Citer cet article}

Deaville, J. (1997). The Organized Muse? Organization Theory and "Mediated" Music. Canadian University Music Review / Revue de musique des universités canadiennes, 18(1), 38-51. https://doi.org/10.7202/1014819ar

\section{Résumé de l'article}

Throughout musical history, organizations have occupied a significant role in the production of music. The article explores how scholarship might approach the study of musical organizations through organization theory. After a discussion of modernist and postmodern paradigms in organization theory, the article applies those principles, as well as the thought of sociologist Pierre Bourdieu, to two case studies from the history of the New-German movement. The case studies illustrate how organization theory helps explain the failure of the Euterpe-Verein in Leipzig on the one hand, and the success of the Allgemeiner Deutscher Musikverein on the other.
All Rights Reserved @ Canadian University Music Society / Société de musique des universités canadiennes, 1997
Ce document est protégé par la loi sur le droit d'auteur. L'utilisation des services d'Érudit (y compris la reproduction) est assujettie à sa politique d'utilisation que vous pouvez consulter en ligne.

https://apropos.erudit.org/fr/usagers/politique-dutilisation/ 


\title{
THE ORGANIZED MUSE? ORGANIZATION THEORY AND "MEDIATED" MUSIC ${ }^{1}$
}

\author{
James Deaville
}

Throughout musical history, organizations have played a decisive role in the production and dissemination of musical works. Collectively defined as "present[ing] actors ... with certain common traits and patterns of acting and thinking,"2 such diverse organizations as Telemann's Collegium Musicum in Leipzig of the early eighteenth century, the publishing house Breitkopf und Härtel of the last 275 years and the Stax recording company during the 1960s all mediated a body of music (often new) to a specific group of consumers. Through an introduction to organization theory and an application thereof to two case studies, this article intends to present an argument for regarding music through such mediating agencies and to argue for the value of the perspectives of organization theory. ${ }^{3}$

This topic arises from research into musical societies and performing organizations of the nineteenth century. ${ }^{4}$ In attempting to come to terms with the activities of those groups, the scholar discovers that traditional musicology has tended to focus on the creation and genesis of a musical work rather than the moments at which it has entered the public domain, which the societies, ensembles, and social institutions like the church or the salon have historically mediated. By broadening the inquiry, one realizes that the dissemination of Western art music has largely been mediated by organizations, ${ }^{5}$ a fact that has

1 I thank Prof. R.J. Richardson, Department of Sociology, McMaster University, for his advice in preparing portions of this paper. For a paper that articulates a specific problem case for the relationship between organization and power, see Rob Bowman's contribution to this volume.

2Göran Ahrne, Social Organizations: Interaction Inside, Outside and Between Organizations (London: Sage, 1994), 136.

3 While the concept of the mediation of music is complex, I restrict its meaning here to signify the actual act of transmitting music, whether by publication, live performance, recorded sound, or broadcast. There exist of course other aspects and levels of mediation, involving musical perception and the aesthetic reception of a work of art. Those are dealt with by Antoine Hennion, for example, in his $\mathrm{La}$ passion musicale: une sociologie de la médiation (Paris: Éditions Métailié, 1993). A most recent and interesting discussion of mediation is presented by the article "Critical Musicology and the Problem of Mediation" by Stephen Miles, in Notes 53, no. 3 (March 1997), 722-50.

$4 \mathrm{My}$ research has focused on the German societies and performing organizations associated with the New-German movement of Franz Liszt and Franz Brendel, which for example through the Leipzig concert series Euterpe and the society Allgemeiner Deutscher Musikverein attempted to promote the music of Liszt, Wagner, and their younger German colleagues. In general, research into nineteenth-century musical organizations is still in its infancy. Thus none of the major musical organizations of the nineteenth century have yet been studied in any comprehensive way from the perspective of sociology.

5 Whether the masses of Josquin, the songs of Amy Beach, the big band music of Glenn Miller, or the rap music of Tupac Shakur, some social institution, artistic society, music publisher, or broadcasting 
not always been recognized by musical scholarship, even though Marxism and Rezeptionsgeschichte have taught us that publication and performance occupy key functions in the nexus of social contexts for music. ${ }^{6}$

We need to be aware of the organization's controlling power over what is and has been heard and performed. And with few exceptions, there has been a general scholarly neglect of historical musical organizations from the viewpoint of organization theory. ${ }^{?}$

Before proceeding to a closer examination of organization theory, however, it should be noted that the organization is only one of many factors influencing the transmission of musical works. Also, organization theory itself is by no means the sole means of interpreting that transmission. However, as illustrated through the case studies later in this article, organization theory does bring to light and help to explain aspects of the production and reception of music that might elude more traditional musicological inquiry, and furthemore, it provides a general theoretical basis for the understanding of that which takes place within and around musical organizations.

As a field of inquiry, organization theory is rather difficult to position, for it spreads across such diverse disciplines as sociology, anthropology, economics, and management. ${ }^{8}$ Furthermore, organization theory (like musicology) is currently in the midst of a paradigm crisis: ${ }^{9}$ one may regard it from a traditional "modernist" or "formalist" perspective, or from the position of "postmodernism." 10 The following discussion explicates both approaches to

corporation enabled the dissemination of the music.

6See, above all, the contributions of Carl Dahlhaus regarding Rezeptionsgeschichte, especially "Zwischen Relativismus und Dogmatismus. Anmerkungen zur Rezeptionsgeschichte," Jahrbuch des Staatlichen Instituts für Musikforschung (1981-1982): 139-46 and "Textgeschichte und Rezeptionsgeschichte," in Rezeptionsästhetik und Rezeptionsgeschichte in der Musikwissenschaft (Laaber: LaaberVerlag, 1991): 139-46. The Marxist perspective is presented for example in the "classic" texts of Ernst Hermann Meyer, Musik im Zeitgeschehen (Berlin: Henschel, 1952) and Musik der Urgesellschaft und der frühen Klassengesellschaften (Leipzig: Deutscher Verlag für Musik, 1977).

7 An important exception is Charles Perrow, who, in his essay "The Environment" within the book Complex Organizations: A Critical Essay, 3rd ed. (New York: Random House, 1986), makes a unique attempt within the literature of organizational theory to apply principles of the discipline to music, in a discussion of the history of the popular music industry (pp. 183-89).

8 Symptomatic of this breadth are disparities between academic institutions in the departmental locus of organizational studies, which could be any of the disciplines indicated above.

9 Overviews of recent developments in organization theory are provided in (among others) W. Richard Scott, Organizations: Rational, Natural, and Open Systems, 3rd ed. (Englewood Cliffs, N.J.: Prentice Hall, 1992), Martin Parker, "Post-Modern Organizations or Postmodern Organization Theory?," Organization Studies 13, no. 1 (1992): 1-17 and Stephen Linstead and Robert Grafton-Small, “On Reading Organizational Culture," Organization Studies 13, no. 1 (1992): 331-55.

10 For general discussions of organization theory and postmodernism, see for example Kenneth J. Gergen, "Organization Theory in the Postmodern Era," in Rethinking Organization: New Directions in Organization Theory and Analysis, ed. Michael Reed and Michael Hughes (London: Sage, 1992): 207-26; Paul Jeffcutt, "From Interpretation to Representation in Organizational Analysis: Postmodernism, Ethnography and Organizational Symbolism," Organization Studies 15, no. 2 (1994): 241-74; and Postmodernism and Organizations, ed. by John Hassard and Martin Parker (London: Sage, 1993). Specialized analyses of the influences of Derrida and Foucault are provided by Gibson Burrell in "Modernism, Post Modernism and Organizational Analysis 2: The Contribution of Michel Foucault," Organization Studies 9, no. 2 (1988): 221-35 and Robert Cooper in "Modernism, Post Modernism and Organizational Analysis 2: The Contribution of Jacques Derrida," Organization Studies 10, no. 4 (1989): 479-502. 
organization theory, and subsequently applies each of them to case studies. The organization theory of Göran Ahrne is typical of the literature, and yet appropriate for this study: it is informed by social theory and it defines organization so broadly as to readily allow inclusion of the musical organizations under consideration here. ${ }^{11}$ Ahrne initially identifies "four main features of human interaction that together make up the universal pattern of organization: affiliation, collective resources, suitability of individuals, and recorded control."12 As Ahrne observes, "through their affiliation to particular organizations individuals get access to resources and power, but they are also controlled ..."13 Furthermore, affiliation - whether employment or membership - is controlled as a boundary-maintenance operation by the organization; "the ultimate choice is not yours. You have to be admitted." 14 Affiliation in organizations can be either compulsory or voluntary in nature, associated with the following organization types: families, states, voluntary associations, and business enterprises. Within each of these types, organizations can be grouped into discrete fields of "resource and product consumers ... and other organizations that produce similar services or products." 15 The structures of organizations can be variously defined, whether for example, as the results of varying centripetal and centrifugal forces (Ahrne), or "as the sum total of the ways in which [the organization] divides its labor into distinct tasks and then achieves coordination among them." 16 Coordination and unity are achieved through the organizational culture of the enterprise, which comprises its ideology and goals. Indeed, modernist theorists tend to regard organizations as "structures for coordinating activities in the pursuit of specialized goals." 17 According to the modernist perspective on the organization, all of these elements and processes work together to ensure survival (and ultimately, profitability), for "organizations are ... organic systems imbued with a strong drive to survive, to maintain themselves as systems." 18 And the degree of organic unity, of consensus internal to the organization is considered by modernist theorists to be a hallmark of organizational success.

Up to this point, the discussion has focused on the "inside" of organizations, which is typical of the modernist approach to organization theory. Following these definitions and descriptions, it is possible to construct a modernist enquiry into organizations within any discipline (including music). However, if according to Gergen, "the [modernist] tendency to view the organization as an autonomous, self-contained system ... recedes, and instead, the organization's outcomes ... become inseparable from those of the broader

11 Ahrne, Social Organizations.

12 Ibid., viii.

13 Ibid.

14 Ibid., 7.

15Paul J. DiMaggio and Walter W. Powell, "The Iron Cage Revisited: Institutional Isomorphism and Collective Rationality in Organizational Fields," in The New Institutionalism in Organizational Analysis, ed. by DiMaggio and Powell (Chicago: University of Chicago Press, 1991), 64-65.

16Henry Mintzberg (1979), quoted in Scott, Organizations, 226.

17 Ibid., 315.

18 Ibid., 24. 
community," 19 then we need to look beyond that paradigm in assessing social contexts for music organizations. Most helpful in applying socially informed organization theory to enterprises that produce cultural goods are the insights of Pierre Bourdieu, especially from his article "The Production of Belief: Contribution to an Economy of Symbolic Goods" (1977). ${ }^{20}$ As a sociologist, Bourdieu has exerted a growing influence upon a decade of organizational theorists, both modernists and postmodernists, even though he eschews the "determinism of objectivist analysis." 21 His theory of the field of cultural production has been described as "encompassing the set of social conditions of the production, circulation and consumption of symbolic goods." $22 \mathrm{His}$ major contribution to understanding music organizations would fall in those areas traditionally considered to be "outside" of the organizations, the selection and mediation of the commodity within that field. ${ }^{23}$

In particular, Bourdieu articulates and problematizes the relationships between creator and mediator and between mediator and consumer. In his desire to establish the legitimacy of the cultural field based on economic or political capital, ${ }^{24}$ Bourdieu would overthrow the "charismatic" ideology of creator (i.e., composer) and her commodity (i.e., composition) altogether, establishing a privileged position for the mediating organization:

Who is the true producer of the value of the work - the painter or the dealer, the writer or the publisher, the playwright or the theatre manager? The ideology of creation, which makes the author the first and last source of the value of his work, conceals the fact that the cultural businessman (art dealer, publisher, etc.) is at one and the same time the person who exploits the labour of the "creator" by trading in the "sacred" and the person who, by putting it on the market, by exhibiting, publishing or staging it, consecrates a product which he has "discovered" and which would otherwise remain a mere natural resource ... He is the person who can proclaim the value of the author he defends (cf. the fiction of the catalogue or blurb) and above all "invests his prestige" in the author's cause, acting as a "symbolic banker" who offers as security all the symbolic capital he has accumulated (which he is liable to forfeit if he backs a "loser"). ${ }^{25}$

19 Gergen, "Organization Theory in the Postmodern Era," 223.

20This article is translated by Randal Johnson in Chapter 2 of the collection The Field of Cultural Production: Essays on Art and Literature (New York: Columbia University Press, 1993), 74-111.

21 Randal Johnson, "Editor's Introduction: Pierre Bourdieu on Art, Literature and Culture," in The Field of Cultural Production, 6.

22 Ibid., 9.

23The following articles contain significant applications of Bourdieu to the field of music: Thomas Turino, "Structure, Content, and Strategy in Musical Ethnography," Ethnomusicology 34, no. 3 (1990): 399-412, and Simon Frith, "What is Good Music?" Canadian University Music Review no. 10/2 (1990): 92-102. Hennion unsuccessfully attempts to critique Bourdieu on aesthetic grounds in his La passion musicale, 122-26.

24 Johnson, "Editor's Introduction," 15.

25Bourdieu, "The Production of Belief" 76-77. This line of thinking is of course allied to the "death of the author" approaches to textuality we find in the literary criticism of Roland Barthes and Michel Foucault from the late 1960s and the development of reader-response criticism and the theory of interpretive communities in the work of Stanley Fish (Is There a Text in This Class?) from the 1970s. 
As Bourdieu suggests, the initiative for selecting a given creation comes from the agent or mediating organization, which will then put its symbolic and real capital behind that product and - by association - its creator. The selection process that consecrates the product is itself based on the principle of profitability:

For ... the art dealer, the publisher or the theatre manager, the only legitimate accumulation consists in making a name for oneself, a known, recognized name, a capital of consecration implying a power to consecrate objects (with a trademark or signature) or persons (through publication, exhibition, etc.) and therefore to give value, and to appropriate profits from this operation. ${ }^{26}$

This theory leaves little room for altruism or aesthetic experience as motivating the selection of works for mediation. Selection decisions are made with long-term survival as a fundamental criterion. Perrow's pioneering study of the popular music industry observed how even in difficult times, profitability was maintained and thus survival was ensured:

The costs of turbulence and change, when they occur, are "externalized" ... and thus are borne by artists, producers, and other creative people ... The majors did not show any decline in profits during the turbulence; the costs could be passed on ...27

Regarding the mediation and consumption of cultural goods, Bourdieu establishes two oppositions: between "dominant" and "dominated" positions and between sub-fields of "restricted" and of "large-scale" production. Within the field of cultural production, those organizations in dominant positions (such as the Gewandhaus in Leipzig) possess the needed economic and symbolic capital to serve as an "institution of consecration" of cultural goods within a specific market. ${ }^{28}$ Dominated producers (i.e., other performing ensembles in Leipzig of the era) would wish to overturn the hierarchy, but to obtain the profits, they "have to resort to subversive strategies." 29

The field of cultural production itself is structured by the opposition of the two aforementioned sub-fields. The field of restricted production is defined by Bourdieu as "a public of producers of cultural goods," such as other composers or performers within an organization, while the field of large-scale production refers to production for "the public at large." 30 A producer will expend its economic and symbolic capital in mediating the product within one of these sub-fields (i.e., advertising and performing). And an organization of consecration knows its field of production. Thus

26Ibid., 75.

27Perrow, "The Environment," 185.

28 See Bourdieu, "The Field of Cultural Production, or: The Economic World Reversed," in The Field of Cultural Production, 41-54, for a discussion of the dominant principle of hierarchization and its relationship to consecration.

29 Bourdieu, "The Production of Belief," 83.

30Bourdieu, "The Market of Symbolic Goods," in The Field of Cultural Production, 115. 
choosing the right place of publication ... is vitally important because for ... each form of production and product, there is a corresponding natural site in the field of production, and producers or products that are not in their right place are more or less bound to fail. ${ }^{31}$

As we shall see, these concepts of position and field are valuable resources for the interrogation of specific music organizations of mediation.

Because of his paradoxical position, which one author has described as "staunchly antipositivist, ... nonetheless insist[ing] upon the scientificity of sociology," 32 Bourdieu has resisted attempts to be labelled as a postmodernist. Nevertheless, there exists a growing community of self-identified postmodern organization theorists, who have published extended essays reviewing the foundations of postmodern discourse while attacking modernist epistemology and methodology. ${ }^{33}$ I shall briefly consider the discourse of this group.

It is clear that postmodernism informs these overturners of a system which believed "there were essentials to be discovered through reason and observation." 34 Jeffcutt well articulates the postmodern rejection of modernist organization theory: "As postmodernism informs, the particular hierarchies that have been inscribed in [modernist] Organization Studies, which privilege particular readings and voices while suppressing and denying alternative articulations, are at the same time transient and flimsy ... "35 He and others advocate the adoption of "dialogic forms of expression which enable the communication of ambiguity, heterogeneity and discord," 36 which are fundamental elements of organizational life. However, while they theoretically embrace "a polyphonic, open-ended, creative dialogue," virtually none of the

31 Bourdieu, "The Production of Belief," 95.

32 Nicola Vulpe, "Pierre Félix Bourdieu," in Encyclopedia of Contemporary Literary Theory, ed. Irena Makaryk (Toronto: University of Toronto Press, 1993), 261.

33 See the aforementioned bibliographic items by Gibson Burrell, Robert Cooper, Kenneth Gergen, John Hassard, Paul Jeffcutt, Martin Parker, and Michael Reed. John Hassard has played an important role in publishing the work of these scholars, in such collections as the afore-cited Postmodernism and Organizations, as well as The Theory and Philosophy of Organizations: Criticial Issues and New Perspectives, co-edited with Denis Pym (London: Routledge, 1990) and Hassard's own monograph Sociology and Organization Theory: Positivism, Paradigms and Postmodernity (Cambridge: Cambridge University Press, 1993). For an example of a concerted attempt to come to terms with the contribution of recent thought upon the discipline, see the series "Modernism, Post Modernism and Organizational Analysis," in which the aforementioned articles by Burrell about Foucault and Cooper about Derrida appeared.

34Gergen, "Organization Theory in the Postmodern Era," 212. The dynamics of the confrontation of paradigms within organization theory are clearly described in John Hassard's "Postmodernism and Organizational Analysis: An Overview," in Postmodernism and Organizations, 1-23. Despite a position ostensibly open to the retrenchment taking place within organization theory, Michael Hughes, in his concluding contribution "Decluding Organization" in Rethinking Organization, 299, expresses fears that are familiar from the postmodernism debate in other disciplines: "A linguistic-constructionist 'overturning' treats organization as a non-discrete theoretical, or empirical, category and requires no agency. Should organization theory embrace the discordant voices of linguistic conjury, the narrative will be deprived of a narrator. On this side of the line of asymmetry there is no direction or theory of organization."

35 Jeffcutt, "From Interpretation to Representation in Organizational Analysis," 255-57.

$36 \mathrm{Ibid}$., 256. Of the postmodern organization theorists, Jeffcutt is the only figure to invoke the name and theories of Mikhail Bakhtin, including the polyphonic text, heteroglossia, and the carnivalesque. 
postmodern organization theorists provide examples of practical applications. For Jeffcutt, this dialogue "is inevitably challenging and disconcerting, representing plurality, diversity and paradoxical interactions that are ultimately unresolved," and the quest for understanding is liminal, "appearing to offer a capacity for closure, yet at the same time, remaining irredeemably and creatively undecidable." 37 Indeed, he concludes by quoting Wakefield: "that is the task, not of finding ends, solutions and finalities, but of living in a world from which these privileges and certainties have been withdrawn." 38

While by definition there can be no monologic postmodern system that can be applied to the following case studies, the work of organization theorists like Jeffcutt and Gergen certainly make us aware of the issues that should inform such inquiries. Indeed, Gergen's afore-cited plea for regarding an organization's outcomes "as inseparable from those of the broader community" 39 furnishes a practical key for future interrogation of organizations. 40 And Jeffcutt's analysis of Bakhtin is a useful starting place for developing a dialogue about organizations:

In Bakhtin's $(1981,1984)$ terms, we have the interplay between "canonical" discourses as authoritarian narratives that seek to offer different versions of the last word in the interpretation of organizational culture and symbolism, and "carnivalesque" discourses that seek to subvert and parody the form of any last words as a radical unbounding of those parameters or totalizations. ${ }^{41}$

I shall attempt to introduce this discursive interplay into the following "tale of two organizations," in the course of which I shall draw upon both modernist and postmodern organization-theoretical epistemologies.

\section{Euterpe-Verein, Leipzig}

In 1860 , the New-German musical movement around Liszt, as headed by Franz Brendel, music critic, aesthetician and editor of the Neue Zeitschrift für Musik, attempted to establish a foothold for the music of Liszt and associates in the difficult market of Leipzig. ${ }^{42} \mathrm{~A}$ change in the direction of the amateur orches-

37 Ibid., 262.

38 Ibid., 266-67.

39 Gergen, "Organization Theory in the Postmodern Era," 223.

40 In contrast, Hughes, "Decluding Organizations," 297-300, is more concerned with preserving the discipline of organization theory than with the radical possibilities opened up by the new discourse. His final statement (p. 300): "Re-thinking but not abandoning the field of play."

41 Jeffcutt, "From Interpretation to Representation in Organizational Analysis," 260.

42 Paradoxically, although Leipzig had served in the first half of the century as a site of musical progress and remained after 1850 the publishing center for the so-called "progressive movement" in music, its strong Schumann and Mendelssohn tradition became a hindrance to its acceptance of the New-German muse of Wagner and Liszt. Typical was the reception accorded a performance of the symphonic poem Mazeppa at a benefit of the Gewandhaus in 1857 conducted by Liszt himself, during which laughter and hissing accompanied the more revolutionary portions of the score. See Alan Walker, Franz Liszt, volume 2: The Weimar Years, 1848-1861 (New York: Knopf, 1989), 415-16, for an account of this concert. Keith Johns deals with this concert in detail in his article "Liszt at the Gewandhaus: A Study for the 26 February 1857 Concert," Journal of the American Liszt Society 27 (1990): 39-47 and 29 (1991): 36-46. For a detailed discussion of the historical and social context for the Euterpe experiment of the New Germans, see Deaville, "The New-German School and the Euterpe Concerts, 
tral society Euterpe in Leipzig in the winter of 1859-60 was the opportunity the New Germans were seeking. Brendel, as Director of the Board of Euterpe, engaged the New-German conductor Hans von Bronsart for the 1860-61 and 1861-62 concert seasons. ${ }^{43}$ Immediately upon appointment, Bronsart set about his work by introducing a modern repertoire of New-German works by Liszt, Berlioz, and Wagner (see the Appendix for the Liszt works programmed by Euterpe) ${ }^{44}$ However, differences occurred between Bronsart and the Board, which insisted on maintaining authority in programming decisions. An especially bitter debate arose over Bronsart's selection of a radical composition by non-affiliate Draeseke, with the Board retaliating by publicly criticizing the programme decision..$^{45}$ The result of the dispute was that, at the end of the second season, Bronsart resigned his post, which in effect represents the end of the Euterpe experiment, which left no lasting influence in Leipzig: the ensemble itself reverted to a more conservative "product." 46

Viewed from the perspective of modernist organizaton theory, the end result was predictable. Prior to 1860 , Euterpe conformed to the model of a voluntary association, as an amateur concert organization for the recreation of its affiliates, who equally participated in management. ${ }^{47}$ Brendel's assumption of power amounted to a hostile takeover, which appears to have occasioned resentment among the organization's affiliates. ${ }^{48} \mathrm{He}$ changed the organization's goals, modified the Board to protect those goals (the Board was filled with cronies who would sanctify the goals by programme selection), ${ }^{49}$ and

1860-1862: A Trojan Horse in Leipzig," in Festschrift Christoph-Hellmut Mahling zum 65. Geburtstag (Tutzing: Hans Schneider, 1997), 253-70.

43 A pupil of Liszt, Hans von Bronsart (1830-1913) was searching at the time for engagement as conductor.

44Liszt himself became involved in the Euterpe project. Writing to Bronsart on 2 December, he encouraged the talented and reliable New-German propagandist to accept the offer of the "modest yet influential position" ("bescheidene aber doch einwirksame Stellung") (Hans-Rudolf Jung, Franz Liszt in seinen Briefen [Berlin: Henschelverlag, 1987], 178). Perhaps Hans von Bülow best voiced the New-German hopes for the appointment when, ten days before Bronsart's first Euterpe concert on 30 October 1860, he wrote to the conductor "you have in your hands the leadership of a musical revolution for the important city" ("Du hast in Deiner Hand die Leitung einer musikalischen Revolution für die wichtige Stadt") (Hans von Bülow: Briefe, vol. 3, in Hans von Bülow: Briefe und Schriften, vol. 4, ed. Marie von Bülow [Leipzig: Breitkopf und Härtel, 1898], 350).

45 The concert took place in late February 1862 , and the anonymous reviewer for the Neue Zeitschrift criticized Draeseke's Carneval Overture as being "neither understandable nor palatable for the public" (“dem Publicum weder verständlich noch genießbar") ("Kleine Zeitung. Leipzig," Neue Zeitschrift 56, no. 9 [28 February 1862]: 74-75).

46Although Brendel supported the appointment of Bronsart's successor Adolf Blassmann and remained on the Board for several years, his Neue Zeitschrift discontinued its faithful Euterpe reportage of the Bronsart years. Blassmann never clearly became associated with the New-German cause, for as Euterpe chronicler K. W. Whistling notes, he "followed a more moderate course" ("gehörte einer gemässigteren Richtung an") (Whistling, "Die Euterpe als Directorialconsortium," in Der Musikverein Euterpe zu Leipzig, 1824-1874: Ein Gedenkblatt [Leipzig: C.F. Kahnt, 1874], 40).

47Euterpe had been founded in 1824 as an amateur concert association that distinguished itself from the competition by drawing upon the younger musicians of the city. Members essentially managed their own affairs, which included paying themselves from the end-of-year surplus rather than demanding a fixed salary.

48 See Whistling, 39-40, for example.

49 Brendel managed to have the befriended New-German publishers C. F. Kahnt and Julius 
he significantly altered the organization's structure, attempting to convert what was an amateur voluntary association to a professional business enterprise. While Euterpe had always served as an alternative to the Gewandhaus, which represented the dominant institution of musical consecration in Leipzig, Brendel turned it into a competitor, and hence into a dominated producer, who in Bourdieu's words -

in order to gain a foothold in the market, ha[s] to resort to subversive strategies which will eventually bring them ... profits only if they succeed in overturning the hierarchy of the field ...50

It could be argued that the New-German Euterpe did not succeed in overturning the hierarchy because of the dissension that the changes caused within the organization. The committed consumers of the Euterpe product (i.e., subscribers) also appear to have resisted the changes: attendance flagged and the audience and press received these radically new works frequently with hostility. ${ }^{51}$ Such a work of Liszt as the symphonic poem Les Préludes was regarded by the press as "cacophonic" and "offensive." 52 And the Euterpe audience responded to Tasso, for example, with vocal demonstrations of disapproval, which a supportive critic blamed on "several young sons of Israel ... "53

In all, the modernist would analyze the case of the New Germans and Euterpe as representing a good example of an organizational failure in the mediation of music. Examining the organization itself reveals how internal dissension and structural problems can undermine the product and negate the act of consecration, which in the case of Leipzig meant that the Gewandhaus was able to maintain its dominant position and to continue to exclude Liszt's orchestral music for at least one generation of public.

This still does not answer the question regarding why this experiment was unsuccessful among the Leipzig public. While the modernist faction of organizational theorists would blame the inner structural problems, as I have just demonstrated, under the Biblical adage that "a house divided against itself will fall," postmodernists like Gergen would deconstruct that argument, maintaining that "constant challenges to the smooth coordination of internal realities

Schuberth appointed to the Board.

50Bourdieu, "The Production of Belief," 83.

51 Information about the audiences of the Euterpe concerts, from the perspectives of size and make-up, is virtually impossible to obtain, since the organization's business records no longer exist, and other sources of such data, including press reports, Festschriften, and personal memoirs, are not informative in this regard. However, there is no evidence that the audience of Euterpe would have been anything other than the public-at-large that attended the various concert series in Leipzig (including the Gewandhaus concerts). Certainly Euterpe catered to that type of audience until Brendel and colleagues started modifying the organization.

52 "Die schwersten derselben waren Lißt's "Préludes," jene kakophonische Tondichtung, die wo möglich, noch widerwärtiger auf uns gewirkt hat, als früher" ("Correspondenzen. Leipzig," Deutsche Musik-Zeitung 2 [12 January 1861]: 15).

53 "Lißt's Tasso-Sinfonie ... erregte einigen jungen Söhnen Israels Mißbehagen" (Robert Schaab, "Leipzig, im Januar," Euterpe 22, no. 2 [1863]: 35). 
are essential to organizational vitality." 54 Those organization theorists would regard the organization's outcomes in the context of the broader community.

Thus analyzing the case at hand, we realize that the actions of Brendel and his colleagues in Euterpe reveal strategies for marketing their symbolic goods that targeted a very specific audience, which was not the public-at-large. They were attempting to create an elite audience for their new music, which is reflected for example in the advertising and promotion for their cultural product that took place largely within the field of restricted production. In the case of the New Germans, this occurred in their specialist journal Neue Zeitschrift, where criticism further excluded the public of non-producers, thus conforming to Bourdieu's comment that "by attesting the intelligibility of works which were bound to remain unintelligible to those not sufficiently integrated into the producers' field." 55 And the Gewandhaus itself was not going to provide the audience, for "those in dominant positions operate essentially defensive strategies, designed to perpetuate the status quo by maintaining themselves and the principles on which their dominance is based." 56 Furthermore, Leipzig itself was not the "natural site" in the field of production for Liszt's orchestral music at that time, and to reiterate Bourdieu, "producers or products that are not in their right place are more or less bound to fail." 57

What was the problem with the product, that it would find difficulty finding acceptance in a market like Leipzig? Its aesthetic value needs to be taken into consideration. Specifically, I believe that Liszt's music made certain expectations of the audience that could not be accommodated by the existing subscription concert series, whether Gewandhaus or Euterpe. This reflected of course the two camps established during the course of the 1850s over the issue of programme music. I shall return to this vital consideration in the context of the second case study.

\section{Allgemeiner Deutscher Musikverein}

Quite the antipode to the Euterpe experiment, this Society provided Liszt and his New-German associates with a firm organizational basis to achieve their goals. Founded by Liszt and Brendel in 1859, the Society served the stated purposes of "cultivating musical art" and "promoting musicians," which primarily occurred in the initially irregular, then yearly festivals (1859 in Leipzig, 1861 in Weimar, 1864 in Carlsruhe, 1865 in Dessau, etc.).$^{58}$ Like Euterpe, those festivals presented the new music by Liszt and his colleagues, and thus there are many similarities in programming (see the Table). In fact, the ADMV as organization provides a good comparison with Euterpe under Brendel, because

54Gergen, "Organization Theory in the Postmodern Era," 223.

55Bourdieu, "The Market of Symbolic Goods," 116.

56Bourdieu, "The Production of Belief," 83.

57 Ibid., 95.

58Unfortunately, the definitive history of this important new-music society has yet to be written. A good introduction to its first fifty years is provided by Arthur Seidl in the Festschrift zum fünfzigjährigen Bestehen des Allgemeinen Deutschen Musik-Vereins (Berlin: Allgemeiner Deutscher Musikverein, 1911). 
of their numerous similarities: Brendel served as Director of the Board of both Musikvereine, they had homologous internal structures, and produced the same cultural goods. Also, between 1859 and 1861, Leipzig was their common site of production. Nevertheless, the differences are decisive: the purpose in founding the ADMV was not to establish Liszt's music in a difficult market through a business enterprise that would challenge the dominant organization of consecration, but rather to celebrate his role as pioneer of the New-German avantgarde in a voluntary association that was rooted in German festive culture. As a new creation, the Society could establish its own organizational goals, rules for affiliation, internal structure, and priorities for mediation of the product.

The Society went through various inner struggles, but the existing organizational systems and structure were adequate to carry it through, also in face of external opposition. The ADMV eventually attained to a dominant position, from which it could mediate the music of Liszt and his colleagues for decades to a national market. ${ }^{59}$ The modernist organization theorist could look at the ADMV itself and see the basis for this success in the harmony and consensus that appears to have prevailed internally within the organization.

But such an analysis would overlook some of the disjunctions that appeared within the Society's organizational culture, such as between fields of production. On the one hand, it was a closed system: consecration of product was only available to members (and not symbolic affiliates), i.e., to the field of restricted production (other producers within the organization). However, that commodity was not only mediated to the field of restricted production (i.e., to other producers within the organization), but also to the field of large-scale production (i.e., the public-at-large at the various sites of production). While the ADMV may have drawn on the same public-at-large as did Euterpe when its festivals took place in Leipzig, the former did not regard Leipzig, nor any other one German city, as the natural site for the field of production of its cultural goods. And since the Society relied both on producers and public-at-large, the diverse voices assured a healthy discourse regarding the intelligibility of its product, which we can regard as the basis for the broad support the undertaking achieved. As documented by the records of the Society and the press reports for individual festivals, there arose a creative tension between fields of production, in which the festivals became the site of this dialogue between producers and non-producers or consumers, affiliates and non-affiliates. ${ }^{60}$ The festival concerts, lectures with discussions, and social activities, as well as the local and national press, all provided contexts for the dialogue. ${ }^{61}$

59The 1870s and 1880s were the decades of ascendancy and domination for the ADMV.

60The Archive of the Allgemeiner Deutscher Musikverein is preserved at the Goethe- und SchillerArchiv of the Stiftung Weimarer Klassik in Weimar. Its rich holdings encompass over 300 largely uncatalogued folders of material, which - in the form of correspondence between Board members, business papers, press clippings, etc. - provide fascinating insights into the politico-economic struggles surrounding the Society.

61 The tendency in Seidl and other literature about the ADMV is to emphasize its service to the cause of musical modernism, as seen in its advocacy of Liszt, Wagner, Strauss, Delius, and Reger, among other composers. By so doing, however, they ignore this dialogue which was central to the functioning and even the very existence of the Society. The value of the dialogue is made clear in a festival review 
The festivals themselves were well suited for this social polyphony, based as they were in what Mikhail Bakhtin has termed "popular-festive" culture. ${ }^{62}$ And the festivals, whatever their location, were the "natural site" in the field of production for Liszt's orchestral music, originating as much of it did in the popular-festive culture of Weimar. It can be argued that artworks arising under that culture's influence tend to encode carnivalesque elements, in particular the carnivalesque body. And indeed, it is the carnivalesque body that we can find inscribed in Liszt's orchestral music, and that is manifested in subversive qualities of the music. While space does not permit analysis of the music along these lines here, a study of works like the Faust Symphony or Prometheus suggests how, using carnivalesque devices like open, subverted, "unfinalizable" forms and the maskings, unmaskings, and other permutations associated with thematic transformation, Liszt may have encoded the body in his Weimar-era music. Typical of the reception of these works in the press are references to physical responses within auditors, such as the great heat evoked by Prometheus in Vienna, ${ }^{63}$ or discussions of the music in light of bodily functions, like the even more carnivalesque description of the Gran Mass in Leipzig as a "rough and undigested mass," 64 in other words, associated with a lower bodily function. When presented within the context of popular-festive culture, this music of the body spoke to both sides of the dialogue, the fields of restricted and of large-scale production.

However, working against the meaningful, effective mediation of this music outside of popular-festive culture was the transformation of the concert hall into a museum, with all of the accompanying "body-snatching" rituals. ${ }^{65}$ Needless to say, music that mapped the carnivalesque body could not succeed under such conditions as prevailed in dominant, monologic performance organizations like the Gewandhaus in Leipzig. And thus the creation of the

by H. S., entitled "Dritte allgemeine Tonkünstler-Versammlung in Carlsruhe," in Symphonia: Fliegende Blätter für Musiker und Musikfreunde 6 (1866): 97: "The first social gathering, which would repeat itself on a daily basis, took place on the same evening, in the meeting place of the society Eintracht. The very active social life, which manifested itself in cordial compromise and exchange of various artistic opinions, was elevated by a tone that always maintained the dignity of art." ("Denselben Abend fand die erste, der sich nun täglich wiederholenden geselligen Zusammenkünfte in dem Lokal der Gesellschaft 'Eintracht' statt. Das sehr bewegte Leben, welches sich in herzlichem Entgegenkommen und Austausch der verschiedenen Kunstmeinungen kund gab, wurde durch einen Ton gehoben, welcher stets die Würde der Kunst im Auge behält.")

62See Bakhtin, Rabelais and His World, trans. Helene Iswolsky (Cambridge, Mass.: The M.I.T. Press, 1968), especially pp. 196-277.

63 "We do not want any music that leaves us inwardly cold and bores us, while tearing apart our ears through dreadful discords and makes us outwardly scalding hot" ("Wir wollen keine Musik, die, indem sie durch gräulich Mißklänge unsere Ohren zerreißt, und uns äußerlich brühheiß macht, innerlich kalt läßt und langweilt!") (S. B. [Selmar Bagge], "Das alte Wien und die 'neudeutsche' Musik," Deutsche Musik-Zeitung 1, no. 10 [3 March 1860]: 74.)

64 "For the Gran Mass we have only the designation by Ovid: "chaos, rough and undigested mass." ("Für die Graner Messe haben wir nur die Ovidsche Bezeichnung: [Chaos], rudis indigestaque moles!") ([B. Senff?], "Dur und Moll. Leipzig," Signale für die musikalische Welt 17, no. 27 [9 June 1859]: 292.)

65 Peter Burkholder has described the phenomenon of the "museum piece" in his articles "Museum Pieces: The Historicist Mainstream in Music of the Last Hundred Years," Journal of Musicology 2 (1983): 115-34, and "The Twentieth Century and the Orchestra as Museum," in The Orchestra: Origins and Transformations, ed. Joan Peyser (New York: Schirmer, 1986), 408-33. 
ADMV was necessary for Liszt, to provide him with an organization for the mediation, and hence sanctification, of his music throughout Germany, which would remain an organizational goal for the next three decades. More significantly, however, the ADMV enabled the establishment of a polyphonic, open-ended, creative dialogue between producers and consumers of cultural goods.

As I have attempted to illustrate through these case studies, we can fruitfully apply organization theory in the study of the mediation of music. And the difference inscribed in the prevailing modernist and postmodern modes of discourse within organization theory can itself be profitable for the study of mediated music, if the modernist paradigm makes us aware of organizational issues that postmodern approaches can problematize. Indeed, this discursive interplay may serve as our best protection against reinscribing monologic hierarchies of representation. While the outcomes of this polyphony of heterogeneous voices may never be certain or closed, the dialogue represents the opening of possibilities and opportunities, in which we as scholars should revel.

Table: Comparison of Programming of Liszt Compositions by Euterpe and Allgemeiner Deutscher Musikverein

*=works performed by both organizations

Euterpe-Verein, Leipzig

\section{0-61 Season}

Tasso, Lamento e Trionfo*

Les Préludes

Der entfesselte Prometheus*

Hungarian Rhapsody No. 2

Hungarian Rhapsody No. 6

Polonaise brillante, Op. 72 (Weber)

Sonata in B Minor*

"Es muss ein wunderbares sein"

"Du bist wie eine Blume"

"Mignon"*

"Loreley"*

\section{1-62 Season}

Festklänge*

Faust Symphony*

Festmarsch zur Goethe-Jubiläums-Feier

Hungarian Rhapsody No. 9

Hungarian Rhapsody No. 13

"Tarantella di bravura" on La muette de Portici

"Große Phantasie" in C Major, arranged for piano and orchestra (Schubert)

"Soldatenlied" from Faust

"Mignon"*
Allgemeiner Deutscher Musikverein

Leipzig, 1-5 June 1859

Tasso, Lamento e Trionfo*

Gran Mass

"Loreley"*

"Mignon"*

"Lenore"

\section{Weimar, 5-8 August 1861}

Der entfesselte Prometheus*

Faust Symphony*

Piano Concerto No. 2 in A Major

Carlsruhe, 21-26 August 1864

Festklänge*

Mephisto Waltzes for piano and orchestra

Psalm 13

Hungarian Rhapsody

"Großes Konzertsolo"

Sonata in B Minor* 


\begin{abstract}
Throughout musical history, organizations have occupied a significant role in the production of music. The article explores how scholarship might approach the study of musical organizations through organization theory. After a discussion of modernist and postmodern paradigms in organization theory, the article applies those principles, as well as the thought of sociologist Pierre Bourdieu, to two case studies from the history of the New-German movement. The case studies illustrate how organization theory helps explain the failure of the Euterpe-Verein in Leipzig on the one hand, and the success of the Allgemeiner Deutscher Musikverein on the other.
\end{abstract}

